Tatjana Jukić

University of Zagreb

\title{
Ophelia Antigonized: A Pre-Raphaelite Hamlet for Industrial Modernity
}

Understanding modernity seems to be inflected in the narrative conditions of Hamlet: Hamlet may be to modernity what the story of Oedipus is to psychoanalysis, a specimen story in which the intellectual constitution of modernity is decided. In this essay I analyze how industrial modernity finds its articulation in Hamlet, especially in the positions where Hamlet is claimed for realism; realism is taken to mean not a poetics so much as an apparatus instrumental to negotiating the modern condition in the nineteenth century. With a focus on John Everett Millais's Ophelia (1851-2), I discuss how Ophelia replaces Hamlet as a figure where realism is negotiated in Victorian modernity, also as a figure where modern psychopolitics, with its investment in mourning, finds its foothold in the world of the Industrial Revolution. Lastly, I argue that Ophelia may be where the unresolved narrative conditions of Antigone are retained in Hamlet, along with the political concerns implicit to Antigone's mourning.

Key words: industrial modernity, Hamlet, Ophelia, realism, the Pre-Raphaelites, Antigone

\section{Opening remarks}

Understanding modernity seems to be inflected in the narrative conditions of Hamlet: Hamlet may be to modernity what the story of Oedipus is to psychoanalysis, a specimen story in which the intellectual constitution of modernity is decided. Freud has been credited with an "unprecedented transformation of narration into theory" (Felman 1022) for his reading of Sophocles' Oedipus Tyrannus; the same may be true of Walter Benjamin, when he argues for a special status of Hamlet in modernity. Benjamin singles out Hamlet as an exemplary mourning play (Trauerspiel), that literary genre where mo- 
dernity, according to Benjamin, finds its emphatic early articulation. ${ }^{1}$ It has been noted that Hamlet is exceptional to Benjamin because it "both exceeds and confirms the basic parameters" of the mourning play (Comay 266-67). In Hamlet, therefore, the very constitution of modernity seems to be both decided and exceeded, just as modernity, by this account, receives its confirmation only by a measure of (literary) excess.

In this essay I analyze how industrial modernity finds its articulation in Hamlet, especially in the positions where Hamlet is claimed for realism in the nineteenth century: realism in the nineteenth century being not so much a poetics as an apparatus instrumental to negotiating the modern condition. It is in this sense that realism may be a measure of (literary) excess in which industrial modernity is decided. After all, with its focus on narrative genres, realism anticipates precisely the "unprecedented transformation of narration into theory" that Shoshana Felman associates with Freud's psychoanalysis, invested as psychoanalysis is in figuring out modern rationality.

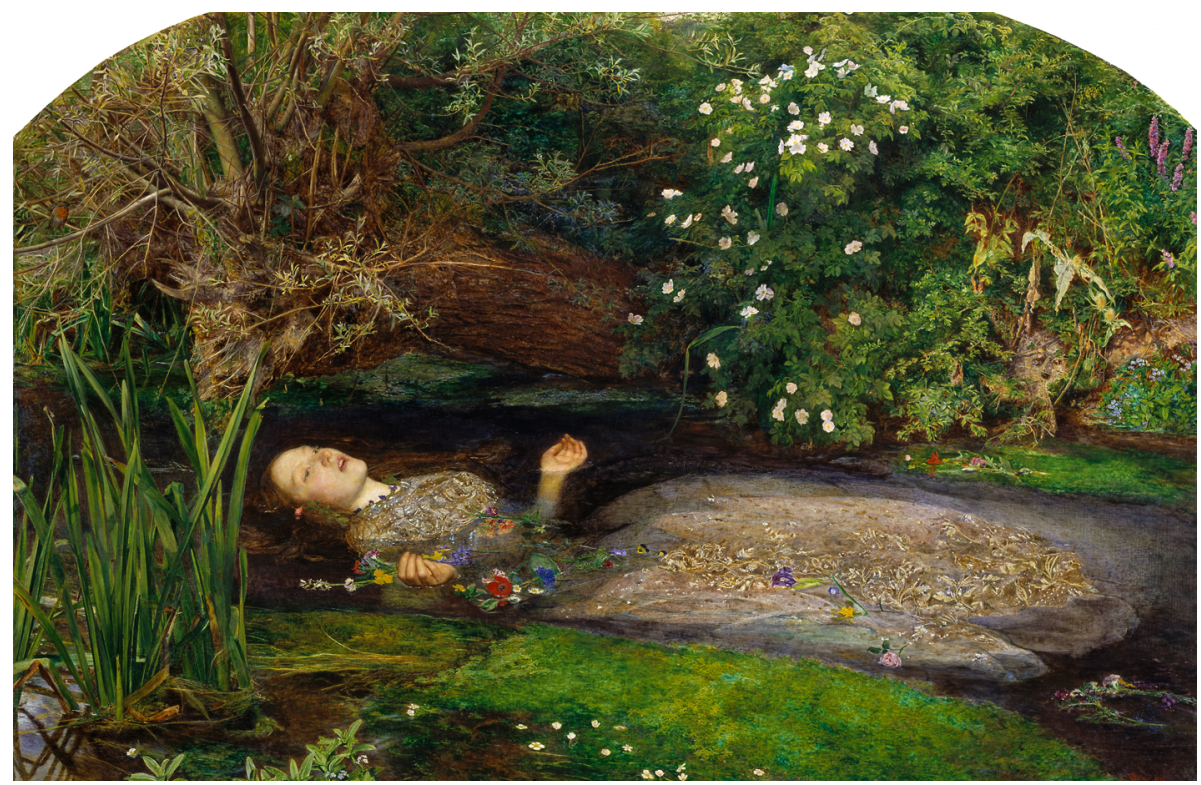

1 See Benjamin 163.

Figure 1. John Everett Millais, Ophelia (source: Wikipedia) 
These different concerns converge in John Everett Millais's Ophelia (fig. 1), a painting that came to exemplify the Pre-Raphaelite truth to nature to the Victorians in the early 1850s, at the time when the Pre-Raphaelites provoked Charles Dickens and John Ruskin, the champions of Victorian modernity, to lock horns over the meaning of realism. ${ }^{2}$ What interests me about Millais's Ophelia is not only its realism, but also how its realism is informed by the structures of mourning, with Ophelia taking over from Hamlet as a figure where mourning and melancholia are negotiated in Victorian modernity. I argue that Ophelia may well be a figure where the unresolved narrative conditions of Antigone are retained in Shakespeare's Hamlet, as well as the political concerns that are implicit to Antigone's mourning. Indeed, Millais foregrounds the Antigonic aspect of Ophelia in his painting, as if to suggest that Ophelia Antigonized is how to figure out both the truth of realism and the politics of industrial modernity.

In order to unpack this configuration, I first turn to Carl Schmitt's reading of Hamlet; for Schmitt, Hamlet is a means of negotiating the literary excess of early modernity into political excess, or perhaps into pure politics. A comment on the Industrial Revolution reveals, however, an unsuspected Antigonic aspect to Schmitt's Hamlet and to his political theory, in which modernity opens up to further investigation.

\section{Hamlet and Industrial Modernity}

Drawing on Benjamin, Schmitt argues for an exceptional status of Hamlet in the ideation of modernity. In Hamlet or Hecuba, he identifies Shakespeare's play as a specimen story of modern revolutions; according to Schmitt $(54,56)$, Hamlet is the first stage of the English Revolution in the seventeenth century, the English Revolution being how the interpellation of political modernity took place. Schmitt explains the exceptional status of Hamlet in part by the fact that revenge in this play is emphatically inflected in reflection, so

2 For the concept of realism in the 1850s, see Brooks 71-72. 
that the embryonic modern sense of authority, and of politics, takes shape in this inflection. In his words, Hamlet "enticed those in positions of authority into a continuous examination of their conscience that led to the loss of the capacity to rule" $(72)$. While Schmitt $(21,24)$ calls this the Hamletization of revenge, what seems to be at stake is the Hamletization of authority in modernity, and of modern governance, so that the idea itself of modern politics appears to be encoded from within the process of Hamletization, with Hamletization as "a vehicle of modernization" (Leonard 202).

Insofar as Hamletization entails the structures of mourning, this means that modern authority is inextricably bound with mourning and melancholia. After all, Hamlet is an exemplary mourning play, and Schmitt describes Hamletization as the transformation of the figure of the avenger into a reflective, self-conscious melancholic (Honig 147; Leonard 202). For Schmitt, mourning and melancholia thus become an index of modern psychopolitics, to borrow a term from Peter Sloterdijk (2010), just as modernity is thereby identified as a psychopolitical excess. As Carsten Strathausen notes in an essay on Hamlet or Hecuba, what "'stands behind' Hamlet's melancholy is . . . the monumental dawn of the entire modern era as such" (19). This further implies that mourning and melancholia in modernity cannot be accessed except as psychopolitics - that, in modernity, there may be an immovable political excess to mourning and melancholia. Cathy Caruth suggests as much when she identifies "an anticipation of Freud's distinction between mourning and melancholia" in John Locke's Essay Concerning Human Understanding, after having identified Locke's empiricist philosophy as political theory. In Caruth's words, "what seems at first a straightforward observation of sensory mechanisms becomes more like an anxious story of a precariously governed state" $(12,34)$. If this means that Hamletization informs not only the English Revolution, strictly speaking, but also philosophy and political theory in its wake, it also suggests that Freud's psychoanalysis, in part at least, is an exercise in Hamletization. 
Finally, by arguing for the preeminence of Hamlet, Schmitt, like Benjamin, implies that literature, not philosophy or theology, is where the ideation of modern authority finds its point of departure. Miriam Leonard notes that, "[i]n self-consciously locating the meaning of Hamlet in its concrete historical setting, Schmitt was making an appeal for the repoliticization of literary analysis" (197); Carlo Galli observes that "Schmitt self-consciously exposes himself to the accusation of effecting a contaminatio between art and politics" (65). David Pan writes that Schmitt's "interest is not just in literary critical issues but also in the reasons that literature is inseparable from politics" (732). This means that in modernity there may be a political excess to literature too, and not only for Schmitt, by which literature itself is confirmed and exceeded (hence, perhaps, the obsessive concern with artistic autonomy in modern literary and critical theory).

That the Industrial Revolution was indebted to this constellation, and to Hamletization, can be inferred from Schmitt's comment that England of the English Revolution later became "the country of origin of the industrial revolution, without having to pass through the straights of Continental statehood" (55-56): it was the country that "did not set up a state police, justice, finance or standing army in the way Continental Europe did" (56). Schmitt implies that the Industrial Revolution resulted from a systemic revolutionary character that England retained between the seventeenth and the nineteenth centuries; he suggests that the Industrial Revolution began as political, adopting and furthering the language of Hamletization. That no less than modernity was at stake can be inferred from a comment by Eric L. Santner, that Schmitt's early modern England "was ... prematurely developed, historically more advanced, already moving beyond the order of territorial states that defined the politics of the Continental powers" (155). Santner alludes here also to Schmitt's earlier research, in Land and Sea, where the focus was not only on the English Revolution but also on England's espousal of sea over land: Schmitt's revolutionary England progressing "from one order of deterritorialization to another, even more radical one that shifted the center of gravity of 
political power from land to sea" (155-56). Even so, as Strathausen notes, the shift from land to sea too was "concentrated on the side of revolution" (20), contributing to the transformation of the world that was eventually fully effected by the Industrial Revolution. It is almost as if England's shift from land to sea was a stepping stone between the English and Industrial Revolutions, opening the world itself to revolutionary transformation. ${ }^{3}$

By this account, the Industrial Revolution was truly a revolution worthy of its name: not because it dovetailed with the English Revolution, but because it transformed the very conditions of and for the revolution in the modern world. As Christoph Menke notes, "what the revolution primarily transforms ... is how historical transformation is enforced. The revolution transforms transformation" (321). The Industrial Revolution kept refracting the conditions of the other revolutions that shaped the political profile of the long nineteenth century: the American Revolution, the French Revolution, the Russian Revolution. When Eric Hobsbawm (1996) argues for the Dual Revolution as a concept that explains the historical logic of the nineteenth century - the Dual Revolution designating a coming together, in the nineteenth century, of the Industrial Revolution and the legacy of the French

3 That Schmitt was critical of industrialization (pointedly so in Land and Sea) is a staple of Schmitt scholarship. See Meierhenrich and Simons 41; Bendersky 128, 142; Teschke 395; Simons 780-81. Hence the special importance of his claim in Hamlet and Hecuba, that the Industrial Revolution proceeds from seventeenth-century English sovereignty, given that seventeenth-century England had a lasting fascination for Schmitt and in many ways remained a cornerstone of his political thought. Admitting the Industrial Revolution to this fascination constitutes a rupture in Schmitt's political theory - a rupture comparable to the historical intrusion (Einbruch) that he identifies in Hamlet and associates with the inception of modernity. The Industrial Revolution in Hamlet and Hecuba was therefore how Schmitt's political theory was itself subjected to Hamletization. Pan, for instance, comments that "Schmitt seems to forget his own pronouncements about the primacy of the political ... when he refers to the new order as the one of maritime existence and the Industrial Revolution" (748). Rather than an instance of forgetting, however, the Industrial Revolution seems to be an instance of Hamletization in the very theory whose aim is to explain Hamletization. 
Revolution - he assigns a similar value to the Industrial Revolution, implying that the transformation brought forward by the French Revolution does not suffice to explain the structure of nineteenth-century modernity.

\section{Truth to Nature and Pathetic Fallacy}

A Victorian Hamlet that came closest perhaps to probing this juncture was Ophelia (1851-2), a painting by John Everett Millais. It was at this time that the Pre-Raphaelites, having vocally adopted "truth to nature" as their creed, provoked a heated debate among the Victorians not merely about the exact meaning and function of realism in literature and art, but about realism that - in targeting nature - targeted actually the ongoing transformation of the world in the Industrial Revolution. The question that informed the Pre-Raphaelite creed, therefore, was this: What constitutes truth to nature if nature is predicated on transformation? The Pre-Raphaelite nature was in fact true only to the modern world engaged in its totality by the Industrial Revolution: the totality also to do with the fact that the industrial transformation coincided with the intellectual breakthroughs of Victorian geology, with its emphasis on the ongoing planetary transformation. Victorian modernity, in other words, was acutely paleotechnic, to paraphrase Lewis Mumford (1934).

As a painting that opened in exhibitions, a matter of public display, Millais's Ophelia coincided conveniently with the Great Exhibition of 1851, itself a vehicle of the modern world engaged in radical transformation. The name of the exhibition was the Great Exhibition of the Works of Industry of All Nations, a historic event whose ambition was not merely to represent the world as industrial in its totality, but also to testify to a truth implicit to this world. The Exhibition was housed in the novel architecture of the Crystal Palace, as if to suggest that Victorian exhibition areas came to replace, in the nineteenth century, the theatrical spectacularity of early modernity. Fittingly, the Crystal Palace entertained the idea of industrial architecture and accommodated an appropriate sense of transformative thermodynamics: The Times 
reported on "the bright hot sun shining on its ribs and sides," so that "[t]he heat of the sun, acting on the moist ground, produced a fluctuating haze or mist, through which the procession appeared in the same shifting uncertain light that you see in the magic lantern, and added an air of unreality to the scene" (I. Armstrong, Victorian 142). That realism was negotiated in the process can be inferred from the fact that "an air of unreality" occasioned by the scene was quickly explained by The Times as the reality of the ground and the heat that were being redistributed in the new architecture, suggesting that no less than a truth of realism was vested in this (paleotechnic, metonymic) redistribution.

The tone of the debate about the Pre-Raphaelite truth to nature was set by Charles Dickens and John Ruskin; the debate took place mostly in Household Words and The Times, in 1850 and 1851. Of course, a more general truth of Victorian modernity was canvassed in this discussion, insofar as Dickens and Ruskin were instrumental to Victorian self-reflection in the mid-century - as instrumental as the Great Exhibition, the Crystal Palace, or The Times and Household Words. The discussion was triggered by a painting Millais had exhibited earlier at the Royal Academy, Christ in the House of His Parents (1849-50), so that Ophelia, painted by Millais in the immediate aftermath of the debate, could be considered Millais's response to the argument. Tim Barringer (61) reports that, following the publication of Ruskin's letter in The Times in 1851, Millais made contact with Ruskin and, his "resolve redoubled by meeting the critic," began painting Ophelia from nature in Surrey later that summer. In many ways, Ophelia was how Millais unpacked his early Christ, so that his Christ was redistributed in Ophelia as heat and the ground were redistributed in the Crystal Palace. ${ }^{4}$

\footnotetext{
4 Schmitt (68) argues that Shakespeare's Hamlet occasioned a similar unpacking in seventeenth-century England, where the Reformation was "unlike any other" in continental Europe, resulting in the "atomization of institutional religion alongside a growing skepticism," with no Counter-Reformation in tow.
} 
Dickens initiated the debate in 1850 by furiously attacking human form in Millais's Pre-Raphaelite "contemplation of a Holy Family" (265). For Dickens, " $[\mathrm{w}]$ herever it is possible to express ugliness of feature, limb, or attitude, you have it expressed" (266), the Millais bodies so vile that Dickens qualifies them as hallucination. Millais's painting engages "the lowest depths of what is mean, odious, repulsive, and revolting" (265); Millais's Christ is "a hideous, wry-necked, blubbering, red-headed boy" and Mary is "so horrible in her ugliness, that (supposing it were possible for any human creature to exist for a moment with that dislocated throat) she would stand out from the rest of the company as a Monster" (265). This is why Millais's painting, even with its realism of detail, both animate and inanimate, fails for Dickens in terms of realism - because these details, taken together, demonstrate the "perversity of mankind" (266); instead, human form should receive its coherence from being "the expression of the human face divine on Earth" (265). Once this rationale is taken to pieces, as Millais takes it to pieces, realism gives way to what Dickens describes as perversity and hallucination.

When Dickens specifies the rationale of realism to be "the expression of the human face divine on Earth," he actually defines realism in terms of substitution and identification, as metaphor; indeed, truth to nature, or the truth of realism, resides according to Dickens in the "pure spiritual condition" (265) of humanity. What offends him about Millais, then, is that this very rationale is dismantled into a metonymic grouping of detail - that the rationality of metaphor is taken to pieces and subjected to metonymic transformation. Isobel Armstrong alludes to the metonymic imperative of Pre-Raphaelite realism when she notes that the Pre-Raphaelite detail "did not necessarily mean 'microscopic' detail, an element that Ruskin introduced into the debate in what was actually a critique of Millais .... It did mean sensuous plenitude" ("The Pre-Raphaelites" 21). Similarly, Julie F. Codell quotes the Pre-Raphaelites, saying, "It is simply fuller Nature we want" ("Empiricism" 125). Roland Barthes (40) explains this particular condition of realism as the "metonymic confusion" of "the bourgeois sign" in the nineteenth century. When Dickens 
describes Pre-Raphaelite realism as perversion and hallucination, he seems to address precisely that which Barthes qualifies as confusion, but pointedly in terms of psychopathology - just as metonymy is thereby earmarked by Dickens for psychic disorder.

In turn, Dickens's response to the Pre-Raphaelites could be described as hysterical, suggesting that hysteria coincides with a sudden, unexpected loss of metaphor, which is replaced by metonymy. (Sigmund Freud was a great reader of Dickens. Regenia Gagnier reports that David Copperfield "was Freud's favorite novel" [221].) Interestingly, the same structure dominates Hard Times (1854), Dickens's industrial novel and his most vocal critique of the Industrial Revolution. Catherine Gallagher summarizes the novel as "the unmaking of a metaphor," noting that " $\mathrm{t}]$ he strength of the dissociative tendency" in Hard Times "is partly due to the fact that Dickens uses metaphor to connect his plots" (149). According to Gallagher, Dickens's industrial novel "questions the very enterprise of making metaphors in a world where connections, when they are possible, are almost always destructive" (149). If this is to say that the industrial novel, for Dickens, does to the novel what the Industrial Revolution does to the world, this is also to say that the Pre-Raphaelite truth to nature corresponds to the truth of the Victorian industrial novel: Hard Times summarizing, in narrative terms, what began for Dickens as a critique of Pre-Raphaelitism. ${ }^{5}$

5 This may also explain why Dickens was dissatisfied with Elizabeth Gaskell's North and South, an industrial novel he commissioned for serialized publication in Household Words right after Hard Times had been serialized in the same publication. Gallagher remarks that Gaskell favors metonymy and that the principal characters in Gaskell's novel "use, discuss, and ultimately discard the metaphor that Dickens had used, however ambiguously, at the center of his novel" and "repeatedly apologize for arguing analogically," blaming "one another for introducing metaphor" (167). Symptomatically, in a note to his managing editor at Household Words, in October 1854, Dickens echoes his 1850 critique of Millais's metonymic bodies: "Mrs. Gaskell's story, so divided, is wearisome in the last degree ....

[T] hus wire-drawn it is a dreary business" (Gallagher 166-67). 
In his letter to The Times of 14 May 1851, Ruskin confronts the anti-Pre-Raphaelite diatribes. He begins by noting that the Pre-Raphaelites are faithful "to a certain order of truth," to be found in the time-consuming toil they invest in the representation of the minute details of the natural world; it is for this reason, he says, that the Pre-Raphaelites ought at once to be placed "above the level of mere contempt" (Hares-Stryker 101). Like Dickens, Ruskin seizes on detail to describe the Pre-Raphaelites. It is only that detail for Ruskin, instead of perverting the truth and realism, is their foothold, by binding onto itself self-absorbing labor that alone defines humanity. Indeed, instead of focusing on human form, Ruskin focuses on the representation of plants in Pre-Raphaelite paintings, a "botanical study" he finds "invaluable" in terms of "truth as well as feeling" (Hares-Stryker 102). If that is to say that truth and realism entail a metonymic order for Ruskin, insofar as dedication to detail entails an acute relation of a self to what Sami Khatib calls "a non-identical reality" (Eşanu 79), that is also to say that Ruskin's perspective on the Pre-Raphaelites as workmen is of a piece with the representation of work in the Victorian industrial novel, above all by Elizabeth Gaskell: in both cases humanity is claimed for a revolutionary transformation, whose logic is metonymic, not metaphorical. ${ }^{6}$ (Incidentally, Ruskin thought Hard Times "the finest of Dickens's novels," a fact highlighted by Peter Brooks [52] in his book on realist vision.) It is in this sense that Ruskin proposes a different philology for the Pre-Raphaelites, one based in metonymy, whereas Dickens adheres to metaphor. Likewise, their philosophical affinities are different: where Dickens identifies proto-Freudian perversion in the Pre-Raphaelites, Ruskin argues for a Humean, empiricist sympathy. It follows that Ruskin engages humanity relationally, not conceptually - metonymically, not metaphorically - as a function of sympathy, not subject to perversion.

Ruskin's critique of the Industrial Revolution is consistent with his perspective on the Pre-Raphaelites. Ruskin perceives art history to be part

6 See Smith (26-28) about Ruskin's “mistrust of metaphor.” 
of restless critical work, in close contact with discourses of Victorian political economy and geology. Gillian Beer quotes Thomas Carlyle to that effect, who "wrote that Ruskin 'twisted ... geology into morality, theology, Egyptian mythology, with fiery cuts at political economy"' (41); Mumford identifies Ruskin as "the fundamental economist of the biotechnic order," as well as a "paleotect" (The Culture 542, Technics 185). Languages and disciplines combine in Ruskin's writings into a metonymic rationality, in a process that corresponds to relational and paratactic bodies in Pre-Raphaelite paintings. It is a rationality that finds its extreme image in Ruskin's 1884 lectures on the storm-cloud of the nineteenth century, where Ruskin analyzes the Earth itself, with its coal and ore, as it metonymizes into paratactic particles of dust, smoke, filth, "dense manufacturing mist" ("The Storm-Cloud" 26). (The industrial novel mobilizes the same image; Gaskell notes in 1854 that factory chimneys "are constantly sending out one-third of their coal" [82].) The world caught in the industrial transformation is thus matched by the planet caught in a chthonic irruption, to which selves find it increasingly difficult to respond with semi-protective insides. This is why the industrial world presupposes a measure of melancholia: because the self in this world is increasingly ceded and lost to it.

Ruskin equipped this particular melancholia with a theory as early as the third volume of Modern Painters, in 1856, when he outlined the concept of pathetic fallacy (Modern 166-83). Ruskin identifies pathetic fallacy in attempts, mostly literary, to relate to nature in terms of identification and substitution, metaphorically that is, with a self that is reinforced by this process rather than ceded to the natural world. Instead, he argues that nature should be engaged relationally, not conceptually, just as modern mimesis needs to take into account this relational imperative (one we could describe as metonymic). It is therefore as early as pathetic fallacy and long before the stormcloud lectures that Ruskin cultivates "a distinctly ecological philology," as Jesse Oak Taylor calls it (5). It is a philology that harbors a nascent metonymic theory of realism; George Levine describes realism precisely as "a sympathet- 
ic and empathic relation" to "the not-self" (viii). Also, pathetic suggests that this fallacy and philology entail a psychopolitics, and that Ruskin engages the Victorian world on psychopolitical terms. In fact, pathetic fallacy could well be describing Freudian hysteria, insofar as hysteria resides in successful - albeit unceasing - attempts to retrieve metaphor as a measure of the self; on the other hand, the metonymic line that Ruskin is taking invokes sympathy as its underlying psychopolitics, with melancholia as its resident pathology. ${ }^{7}$

Freud will acknowledge that there is an order of truth to this metonymic imperative, and to this pathology, when he observes that melancholic persons have "a keener eye for the truth than other people who are not melancholic," because they see the self for what it is: "petty, egoistic, dishonest, lacking in independence, one whose sole aim has been to hide the weaknesses of his own nature" (246). Additionally, Freud attaches a measure of psychopolitics to melancholia when he remarks that " $[\mathrm{i}] \mathrm{n}$ mourning it is the world which has become poor and empty; in melancholia it is the ego itself" (246, emphasis added). Interestingly, in that same section of "Mourning and Melancholia," Freud claims Hamlet for the truth he assigns to melancholia, even though he earlier analyzed Hamlet as an instance of hysteria. Indeed, Hamlet may be how mourning opens up in Freud's psychoanalysis as an intellectual interval between hysteria and melancholia, psychoanalysis itself an instance of Hamletization. ${ }^{8}$

7 In the words of Gilles Deleuze, sympathy is "not a vague feeling of respect or of spiritual participation: on the contrary, it is the exertion or the penetration of bodies," where bodies "may be physical, biological, psychic, social, verbal" (Deleuze and Parnet 52). That sympathy thus imagined entails a measure of pathology, even today, can be inferred from a comment by Oak Taylor, that "[a]ny consideration of The Storm-Cloud in the Nineteenth Century as an account of climate change must begin by acknowledging that Ruskin's original audience thought he was crazy" (8).

8 Ernest Jones explored this interval in Hamlet and Oedipus (67-68). 


\section{Hamlet Unpacked}

Ophelia was Millais's immediate response to the mid-Victorian debate about realism; over time the painting came to exemplify Pre-Raphaelite poetics, but also Victorian modernity. In a book about the afterlives of Ophelia, it has been noted that "Millais's Pre-Raphaelite Ophelia ... has accrued so high a degree of cultural authority" that " $[t]$ he Millais painting of Ophelia, rather than the figure herself, has more recently become the impetus for artists' statements about the nature of art" (Peterson and Williams 3-4). If that means that Ophelia has succeeded, and derailed, Hamlet as a linchpin of Hamletization, it also suggests that realism in the nineteenth century was ultimately an index of Hamletization and entailed a distinct modern psychopolitics.

Tellingly, in Millais's painting the figure of Hamlet is sidestepped for Ophelia to take over as a vehicle of Hamletization. Millais's field of vision is sharply defined by the horizontal figure of Ophelia as she is drowning, half-submerged in the stream and framed by the Ruskinian dense flora of the river bank. This event is not staged in the play but is reported by Gertrude, having taken place off-stage: Gertrude narrates to others how Ophelia sang while afloat, "mermaid-like," surrounded by her "fantastic garlands" and "her coronet weeds," until pulled "from her melodious lay/ To muddy death" (IV. vii, Shakespeare 113). With Gertrude as narrator, Ophelia's suicide is not elided or repressed by the play, but is relegated to a narrative report that impedes the theatrical vision as a kind of narrative overkill and anticipates the language of the novel. Ophelia thus becomes the play's own homo sacer: she is killed off in the play, like so many others in Hamlet, but her death is not admitted to the theatrical order (only to the order of the narrative), which is how she delimits the concept of theatricality and comes to constitute a theatrical state of exception. Millais, that is, shifts focus to that which the play consigns to the status of theatrical junk, refuse, even pollution, only to identify this junk as the play's state of exception and Ophelia as homo sacer. It is in this sense that Ophelia emerges as an exemplary political figure in Hamlet, more 
exemplary than Hamlet himself. Victorian painting may have inherited this condition from early modern theater: Victorian painters rarely chose to show the instant of Ophelia's death, even though "images of Ophelia were shown more often at the Royal Academy between 1800 and 1900 than depictions of any other Shakespearean heroine" (Rhodes 43 ). ${ }^{9}$

Ophelia is consistently a homo sacer in Shakespeare's play: while her suicide should place her within criminality by early modern standards, the particulars of her burial indicate that her death is stuck between crime and non-crime, just as dead Ophelia falls forever short of constituting proper sacrifice. When Hamlet and Laertes finally claim her death as meaningful, they do it improperly and belatedly, which is how her burial and her possible sacrificial future are both disrupted. Additionally, Ophelia is how a limit to Hamlet's madness is imagined, as well as a limit to the play's rationality: when Laertes describes Ophelia as a "document in madness" (IV.v, Shakespeare 104), another order of madness is introduced into the play, an exception to that which the play espouses as theatrical madness and therefore as theatrical reason. When Laertes describes Ophelia's madness as documentary, it is almost as if realism is anticipated in Hamlet, precisely as a state of exception to a theatrical order of truth.

Finally, Ophelia may be a homo sacer to what modernity itself imagines as its reason. A detail from Millais's letter dated 16 December 1852 sheds light on this proposition: Millais comments on the success of an exhibition to which he sent Ophelia, where he "lost only by some few votes the prize given to Ward's 'Charlotte Corday Going to the Execution"” (Millais 189). It is not only that Ophelia is aligned with Charlotte Corday, the murderess of Jean-

9 According to Giorgio Agamben (1998), homo sacer - a figure he traces back to early Roman law - denotes a human life that can be taken without the murder constituting crime or sacrifice. Agamben identifies homo sacer as an exemplary figure of political modernity, precisely in order to expand on Schmitt's political theory that finds its explanatory text in Hamlet. 
Paul Marat, as if no truly functional distinction persisted - by the mid-nineteenth century - between the story of Hamlet and the history of the French Revolution. It is also that the deaths of Ophelia and Corday evidently serve to revolutionize fully the deaths of Hamlet and Marat. If modern revolutions are predicated on the state of exception, as Giorgio Agamben argues, the deaths of Ophelia and Corday, thus aligned, suggest that the deaths of Hamlet and Marat may not be enough for revolution or, perhaps, that the deaths of Hamlet and Marat may be too much for how revolutions engage homo sacer and the state of exception.

\section{Ophelia as a Focalizing Consciousness}

In a sense, Millais's Ophelia contributed to the nascent modern narrative theory that found its preeminent author in Henry James: cast as the play's homo sacer, whose death is of narrative order but not of theatrical order, Ophelia suggests that narrative is bare life of the theatrical order of truth, which threatens this order with an ever-imminent state of exception.

Shakespeare supports this claim by granting Ophelia a peculiar narrative voice to go with the suicide: it is a voice unvoiced but reported, where bare life is negotiated as a narrative limit. Ophelia's suicidal voice is precisely what Hamlet's voice in soliloquies is not, most conspicuously when the soliloquy is about suicide, as in "To be or not to be ...." If this is how Ophelia diverges from what will become a first-person narrator in the Bildungsroman, this may be how she heralds the instance of the focalizing consciousness in the nineteenth-century novel: the focalizing consciousness denoting the voice and the mind where the boundary breaks between the self and the story, between the narrator and the character, to be replaced by a network of unresolved metonymic relationships. This hypothesis is supported by the fact that "[f]rom the Restoration until the end of the nineteenth century Gertrude's monologue... was truncated for performance so that the lines of the speech that explicitly describe the act of drowning, beginning with 'Her clothes spread wide,' were omitted" (Rhodes 44 ). This suggests that the novel, with its in- 
vention of the focalizing consciousness in the nineteenth century, may have picked up on Ophelia, not on Hamlet, as a figure where a narrative state of exception finds articulation - in the works by Austen, Gaskell, James. . Not to mention the fact that a full-scale invention of the focalizing consciousness, in Austen's novels, coincides historically with industrial modernity, and that the Victorian novel is often understood "as the culmination of a tradition that was part and parcel of the modernization process itself” (N. Armstrong 6).

By granting focus to the off-stage Ophelia, Millais explores the visual imaginary that is implicit to the focalizing consciousness, his Ophelia a comment on how the nineteenth-century novel engages and redistributes visibility and visuality, and anticipates narrative cinema. ${ }^{10}$ It is a visibility to which the theatrical demands are no longer essential. Just as the focalizing consciousness is split between a narrative self and the story (this split being where subjectivation takes place without functional closure), Millais's Ophelia is granted focus only at the expense of a measure of disintegration. She is focal to Millais, but there is no focus to her figure: she is loosely assembled around a face and a half-submerged neck, her hair given up to water, her hands disjointed from the rest of the body, in a dress that could be mistaken for a rock protruding from the stream. She is not a figure so much as a configuration, an assemblage, whose logic is metonymic and syntactical. Shakespeare himself describes Ophelia's suicidal voice in pointedly metonymic terms, as her melodious lay. Melodious lay means that Ophelia's voice, as she is dying, comes across as a metonymic web: it is not a voice so much as an uncontained resonance chamber, in which the voice becomes inseparable from its surroundings - very much the condition of the focalizing consciousness in the nineteenth-century novel. Melodious lay is further made part of yet another metonymic arrangement: it entails a muddy death. Shakespeare reinforces metonymic contiguity of the two by the assonance into which melodious lay

10 For narrative focalization in visual terms see Bal ("Myth" and "Narration"); Miller 124-25; Fludernik. 
and muddy death are brought together (melodious lay - $\underline{\text { muddy }}$ death), assonance meaning precisely a grouping of sound that is based in metonymy and parataxis. This implies that anomic suicide begins in Shakespeare's language where voice as grammar is given up for voice as syntax and parataxis, and where metaphor is given up for metonymy; this also implies that the focalizing consciousness begins in the language of the novel in the position that Shakespeare assigns to anomic suicide. ${ }^{11}$

In addition, Millais dismantled himself as painter into the elements of the focalizing consciousness. While his contemporaries judged Ophelia to be "wonderfully like" Elizabeth Siddal, who sat for Millais for the painting, on her way to becoming a tragic Pre-Raphaelite icon, the painting is also an unexpected self-portrait, Ophelia's features resonating strikingly with the facial features of young Millais in contemporary photographs. Millais himself alludes to his affinity with Ophelia, however jokingly, in his letters from Surrey in the summer of 1851 . He reports himself on the verge of being transformed into Ophelia: "am. . . in danger of being blown by the wind into the water, and becoming intimate with the feelings of Ophelia when that lady sank to muddy death, together with the (less likely) total disappearance, through the voracity of the flies" (Millais 119). Also, it is worth noting that Ophelia provided a script for the subsequent biography of Elizabeth Siddal: Siddal seems "to have become so obsessed with the representations for which she sat as model, 'to have decided to live - and die - a fiction'" (Bronfen 168); Pre-Raphaelite apocrypha consistently flirt with the assumption of Siddal's suicide in 1862, as if in the wake of Ophelia. This all but completes a cross-contamination of Millais and Siddal in Ophelia and, consequently, a radical decomposition of self in Victorian portraiture - composition, quite literally, given up for

\footnotetext{
11 Like metonymy, parataxis favors proximity over substitution, and is mobilized around words, phrases and narrative units added on rather than subordinated. See Auerbach 11-12, Said $\mathrm{x}$. It is for this reason that parataxis is not at odds with syntax as is sometimes argued, but rather engages syntax as a kind of conceptual limit. In Heidegger's words, "we certainly do not take parataxis to mean not-yet-syntactic" (186).
} 
decomposition. Finally, just as Ophelia's grave was disrupted so that Hamlet could finalize the story of the play, Siddal's grave was eventually disrupted so that Dante Gabriel Rossetti could retrieve, for publication, the poems he had buried with Siddal: Rossetti's way of conflating melodious lay with muddy death. ${ }^{12}$

Like Ophelia, the Millais of Ophelia was therefore no longer a figure so much as a configuration, an assemblage in which the artist, the model and the subject were given up for a metonymic network. The idea of self/portrait was deployed in Ophelia only to be taken apart into a visual syntax consistent with the focalizing consciousness in the nineteenth-century novel. By extension, the focalizing consciousness is revealed to entail a decomposition of self: the focalizing consciousness seems stuck in a mourning that cannot forget melancholia as its limit. It is in this sense that the focalizing consciousness is also a comment on the first-person narrator of the great nineteenth-century Bildungsroman: in Freudian terms, the first-person narrator of the Victorian Bildungsroman begins as no longer a mourner (this may be why narrators in Victorian Bildungsromans are always hysterical to an extent). Lastly: if these are the terms on which Millais claims for himself the story of Ophelia (and himself for the focalizing consciousness), this is also how his painting becomes a site of narrative radicalization and narrative autochthony. ${ }^{13}$

12 See Gates (149-50) for Siddal's conflation of her poetic voice with the voice of the drowning Ophelia (especially in "A Year and a Day," a poem Siddal wrote in 1855). See also Rhodes 62-63; Jukić, Zazor 115-16. See Millais (144) for Ophelia as a portrait of Siddal. Julie F. Codell ("Painting" 347) argues that Millais experimented with fusing portrait, self-portrait and narrative painting as early as Lorenzo and Isabella (1848). Effie Gray, Millais's future wife, detected a similar procedure in The Eve of St Agnes, an 1854 drawing Millais based on the eponymous poem by Alfred Tennyson: in a letter to her mother she wrote that " $\mathrm{t}]$ he Saint's face looking out on the snow with the mouth opened and dying-looking is exactly like Millais"” (Rose 44).

13 Isobel Armstrong credits Millais with a narrative grasp of literature: the Pre-Raphaelite group, according to Armstrong, fractured "into three forms of the literary - symbol (Hunt), narrative (Millais) and the icon that fuses meaning and materiality (Rossetti)" ("The Pre-Raphaelites" 23). Andrew Sanders (77) suggests the same when he notes that Millais admired poetry primarily for the narrative, not for lyricism. Apart from fully developing 


\section{Ophelia's Chthonic Condition}

In Ophelia, Millais adopted a visual format that corresponds to the focalizing consciousness by radically foregrounding the scene, so much so that the idea of background is compromised. It is as if the grammar of the painting has been cancelled in favor of its syntax; Paul Barlow describes it as "a painting built from a dense network of interlinking lines, tones and hues" (141). The many details are all foregrounded and knit closely into a claustrophilic parataxis: the reeds, the willow, the robin, the dog roses, the nettles, the forget-me-nots, the purple loosestrife, the violets around Ophelia's neck, the poppies in the stream along with irises, pansies, crowfoot, hyacinths, daisies, cornflowers ..., Ophelia's dress and body undone into a paratactic structure. Charles Darwin may have provided the best description of Millais's procedure when he insisted on "an entangled bank" as his preferred site of contemplation, in On the Origin of Species $(59,360)$. If this is to say that Millais's Ophelia may be a Darwinian entangled bank avant la lettre, this also implies that Darwin's entangled bank, as well as the contemplation that informs Darwin's biology, are configured metonymically and paratactically, like Ophelia, compromising equally the idea of background and metaphor as an intellectual situation.

In short, what happens in Victorian Ophelia is that Hamlet's theatrical

the focalizing consciousness, Austen also anticipated the intimacy between the idea of portrait and the focalizing consciousness, most consistently in Pride and Prejudice (1813). The education of Elizabeth Bennet, the novel's focalizing consciousness, climaxes in an ekphrastic moment: when Elizabeth contemplates Mr. Darcy's portrait in his family gallery. It is only when she sees his portrait that she realizes that, with all her excessive intelligence, she is insufficient to hold the narrative together unless she acknowledges that her focalizing self is refracted in his image. In turn, the Darcy of the portrait reciprocates the structure of the focalizing consciousness: like the focalizing consciousness, Darcy of the portrait is split between the character in the novel and a self in the pictorial regime, but is reducible to neither. Put otherwise, Darcy's portrait confronts Elizabeth with the conditions of her own focalizing self: her self being to the novel what Darcy is to her. Finally, this may be how Austen defines subjectivity and subjectivation: as a withdrawal of the focalizing consciousness from presumption to narrative control. 
junk is reclaimed for the foreground, radically narrativized, and mobilized as the intellectual limit of bare life. This is also how junk is claimed for the state of exception, now as an excess of immanence in industrial modernity - just as narrative could be identified as an excess of immanence within the theatrical order of Hamlet. ${ }^{14}$ Ophelia herself is junk, and emphatically so in Millais's painting: she is caught as she is beginning to rot, her body polluting the stream, a fitting metonymy to Hamlet's early metaphor about something being rotten in the state of Denmark. After all, the first gravedigger identifies water as "a sore decayer" while digging Ophelia's grave (V.i, Shakespeare 118); water as the element of Ophelia's suicide and earth as the element of her grave are thus assembled into a metonymy of rotting. This is consistent with the image of "muddy death" in Gertrude's report and Millais's painting. This is also consistent with the narrative fact that Ophelia is junk to begin with: Ophelia is where sexual reproduction is cancelled most pointedly in the play, Hamlet marking her out for a nunnery. The same applies to Hamlet's identifying Ophelia as metal. Describing her as "metal more attractive" (III. ii, Shakespeare 68), Hamlet alludes both to Ophelia's magnetic attraction, as iron ore is magnetic, and to her sexual invalidity: because only lines later he identifies a nothing between her legs. Elaine Showalter senses an acute contiguity of this Ophelia and Millais's painting when she notes that "the painting has such a hard surface, strangely flattened perspective, and brilliant light that it seems cruelly indifferent to the woman's death" (85). Finally, Millais's Ophelia is consistent with the stakes of the Industrial Revolution: industrial modernity is precisely about how production and reproduction are reconceived, away from sexuality, kinship and metaphor, and into a network of metonymic and chthonic interventions. Millais points to Ophelia as an index of this transformation, which is suspended in Hamlet between the (political) something and the (sexual) nothing - in theatrical, political, and sexual terms, Ophelia is the play's dross or slag. This is equally so from the point of view of

14 See Santner (xxi) for the excess of immanence that defines nineteenth-century modernity, in the wake of the French Revolution. 
psychoanalysis: as a disposable figure of Hamlet's desire (an exemplary Lacanian object $a$ ), Ophelia receives her psychoanalytic sanction from being wasted - from becoming sexual junk, dross, slag. ${ }^{15}$

Millais's chthonic Ophelia is also a comment on mourning as a template of modern psychopolitics: it takes Ophelia to show why Hamlet would be an example of functional, normalizing mourning, just as it takes Ophelia to show why melancholia - not mourning - is in fact revolutionary. As a figure of melancholia, Ophelia threatens Hamlet, so that his mourning ultimately emerges as a functional response to the demands of melancholia that forever unsettle modern subjectivation. In terms of Hamletization, Ophelia may be to Hamlet what melancholia is to mourning in Freud's "Mourning and Melancholia." Indeed, when Freud compares mourning to melancholia, melancholia comes across as the polluting, pathological junk of the world that the ego has failed to process to its advantage, so much so that the ego can no longer sustain itself. With Freud's emphasis on the ego as a work-station and on the world as the potentially menacing junk, there is an industrial edge to melancholia thus imagined. It comes as no surprise, therefore, that Freud distinguishes between the work of mourning and the work of melancholia in economic and industrial terms: the work of mourning is productive, while the work of melancholia is not. ${ }^{16}$ Even as a literary work-station, Oph-

15 In Jacques Lacan's words, "only insofar as the object of Hamlet's desire has become an impossible object can it become once more the object of his desire" ("Desire" 36). Put otherwise: it takes a rotting Ophelia, to be buried, Ophelia as junk, for Ophelia to become fully functional to Hamlet's order of truth. To be sure, Lacan, like Jones before him, warns that nunnery was also a reference to brothel at the time. See Lacan ("Desire" 23) and Jones (86). In the final analysis, however, a conflation of brothel and nunnery only means that Ophelia's sexuality is signally processed into junk.

16 See Freud (244-45, 252-53, 255, 257-58) for phrases like "the work of mourning," "the work of melancholia," "the work which mourning performs" and "the economics of pain." See also Derrida (2006) for mourning imagined as work, specifically in relation to nineteenth-century modernity and to Hamlet as its specimen story. According to Derrida, "mourning is not one kind of work among others. It is work itself, work in general, the trait by means of which one ought perhaps to reconsider the very concept of production" (121). 
elia does melancholia in the positions where Hamlet does mourning (and anticipates hysteria): where he is an accomplished dramatist, producing The Mousetrap and stringing blank-verse soliloquies, she sings mad little paratactic songs in which dead flowers are catalogued into metonymic groupings, the songs finally buried off-stage in what amounts to a theatrical suicide. Still, it is in Ophelia's theatrical suicide, not in Hamlet's productive theatrical work, that the future of the play is mobilized: it is Ophelia's disrupted burial, polluting and unhinged, that propels the play towards its narrative future, not The Mousetrap or the soliloquies. Walter Benjamin implies as much when he points out that Hamlet's end is implicated in "vehement externality," because, "as his conversation with Osric indicates, Hamlet wants to imbibe the fate-saturated air, like a poisonous substance, in one deep breath" (137-38). While Benjamin (138) understands this to be death by chance and not death by decision (which, according to Benjamin, is why Hamlet is a mourning play and not a tragedy), it is worth noting that Hamlet's wanting to die by imbibing "a poisonous substance in one deep breath" rehearses, to a fault, the structure of Ophelia's muddy death: Hamlet's death seems overdecided in Ophelia's off-stage suicide.

Millais therefore does not merely foreground Ophelia's melancholia in his painting, but reveals melancholia itself to be an elaborate structure of foregrounding, where the idea of a functional inside is abandoned. This is why Pre-Raphaelite poetics, with its emphasis on foregrounding, finds its rationale in Ophelia, perhaps even a rationalization. It is a rationalization moored in melancholia and in the truth that melancholia commands (evidently, even for Freud). This is also why the Pre-Raphaelites in the late 1840s and the early 1850s, instead of cultivating maudlin historicism - a charge frequently laid at their door - actually derailed the idea of historicism in favor of a historicity where a sense of revolution finds its point of departure. (Which is to say that melancholia in modernity may be revolutionary before the fact.) In contrast, historicism seems to be accommodated in the idea of mourning: because mourning is how the past work of the ego is eventually claimed for functional 
subjectivation, as an inside and a metaphor (Freud speaks of incorporation and identification, [249]), while the metonymic remains of this work are dismissed, quite literally, as the industrial waste of subjectivation, and consigned to "the external world" (Freud 252).

What receives its true measure of Hamletization through Millais is therefore the chthonic imperative of the Industrial Revolution, in which the underworld (coal, iron, and then oil) metonymized, as the century drew on, into Ruskinian storm-clouds and catastrophic images of expanding pollution and chthonic contamination. What had still been comparatively confined to the entrails of the Earth's crust early in the century (as late as even Charles Lyell's geology in the 1830s) was deconstructed by mid-century into an expansive metonymic apparatus of the industrial world. Mumford captures this industrial Hamletization in an apt metonymy when he observes that the color of iron and coal spread everywhere in the nineteenth century, "from grey to black: the black boots, the black stove-pipe hat, the black coach or carriage, the black iron frame of the hearth, the black cooking pots and pans and stoves," only to ask: "Was it mourning? Was it protective coloration? Was it mere depression of the senses?" (Technics 163).

Millais's Ophelia appears reducible to this metonymy. Arrested between a melodious lay and muddy death, Ophelia is shown as she begins to rot in the stream, the process to be advanced, not cancelled or overturned, by her inhaling muddy waters. The melodious lay and the muddy death thus constitute a single metonymy of chthonic expansion, leading to Ophelia's full chthonic transformation. Millais contributes two fitting details to this transformation. First, he adds a string of violets to Ophelia's half-submerged neck. The violets evidently evoke a chthonic future that Laertes attaches to his dead sister at her grave, in Act V ("Lay her i' the earth; -/ And from her fair and unpolluted flesh/ May violets spring," V.i, Shakespeare 121). Yet, Millais claims the chthonic violets for the present tense of his painting - the violets are springing from Ophelia's fair but polluting flesh as she begins to rot in the 
river. Second, Ophelia's white dress with silver flowers stitched on, which is contiguous with the stream, could be mistaken for a protruding rock formation where metal and fossils are showing: for Millais, there appears to be no functional visual or narrative distinction between Ophelia's metallic attraction in Act III, her muddy suicide in Act IV, and her disrupted burial in Act V.

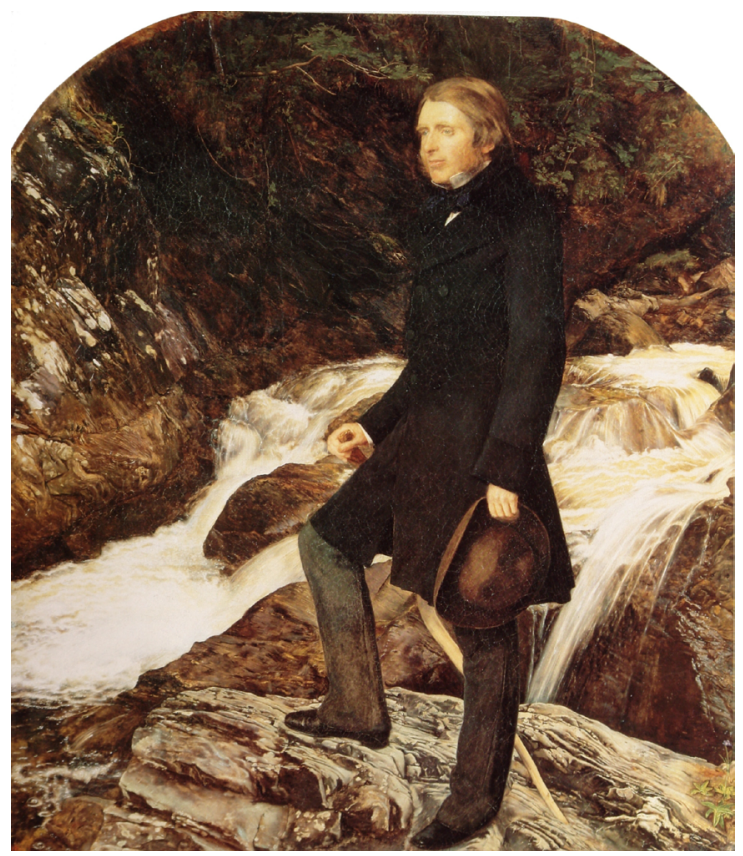

Fig. 2. John Everett Millais, Portrait of John Ruskin (source: Wikipedia)

That these details were important to Millais is backed by his portrait of Ruskin, painted the following year at Glen Finglas, in which a massive whitish horizontal rock formation, suspended in the stream, supports the figure of Ruskin (fig. 2). According to Alastair Grieve, the painting was produced "under Ruskin's strict supervision” and the plan was "to revolutionise British landscape painting and portraiture" (228). While this suggests that Ruskin's portrait was imagined, also, as a detailed geological study, equally striking is the fact that Ruskin's portrait reciprocates the configuration of Ophelia, with a matching metonymic placement of the stream, the plants and the massive 
whitish rock formation in place of Ophelia's body. Solemnly dressed in Victorian black and grey (of mourning? protective coloration? of depression of the senses?) and vertical to what is horizontal about Ophelia, Ruskin appears to be cast by Millais as a Victorian Hamlet at Ophelia's grave. The two paintings could easily be analyzed as companion pieces.

\section{Ophelia Antigonized}

This means that Millais's Ophelia begins for real only when her chthonic condition is foregrounded as she invokes the story of Antigone. Like Antigone, this Ophelia does not merely interrupt the structures of kinship and of politico-sexual reproduction, but inflects them, emphatically, in chthonic terms. ${ }^{17}$

In narrative terms, this modern Antigone is Antigone in reverse, in Millais as in Shakespeare: Ophelia is truly mobilized for the play as she ends, not as she begins, at the critical moment when her suicide rehearses the chthonic conditions of Antigone's suicide. This is to say that the modern Antigone begins in earnest where the Antigone of antiquity ends; this is also to suggest that modernity, insofar as Hamlet is its specimen story, begins by rehearsing Antigone's chthonic condition.

Sophocles' Antigone anticipates, almost to a fault, the continuity between Ophelia's suicide and burial (between the outside and the inside, between the muddy death and the grave), as well as the narrative transformation thus effected. Nicole Loraux suggests as much when she calls attention

17 According to Claude Lévi-Strauss, all Oedipus-related narratives entail a single binary: overrating kinship (and sexual reproduction) vs. underrating kinship (in favor of the chthonic principle and, by extension, of autochthony). Thus Antigone's suicide coheres around chthonic terms, even if it proceeds from overrating kinship (her grieving the death of Polynices). See Lévi-Strauss (214-15, 230). Equally so Lacan: “[I]t cannot be denied that Antigone is after all concerned with the chthonic laws, the laws of the earth" (The Seminar 276-77). Equally so Judith Butler, who remarks in her Antigone book that "Antigone cites the chthonic gods as her authority" (51). 
to Antigone's suffocation: decreed by Creon to be "[b] uried alive, the daughter of Oedipus was doomed to die of suffocation, and in making a noose of her virgin's veil she brought on suffocation by other means" (Tragic 31). ${ }^{18}$ This implies that Antigone does not overturn Creon's ruling, but unsettles and displaces it into a disturbing metonymy: her suffocation by hanging means that she does to herself, by herself, what the earth would do to her by Creon's decree, her body becoming contiguous with the grave, and her suicide with the burial. Her burial of Polynices entails a similar grouping. The body of Polynices is not buried underground; instead, Antigone sprinkles his corpse with a thin layer of dust, which is how the earth, and the chthonic, are mobilized into an expansive metonymy. After Antigone's rites have been undone by Creon's guards, the earth reenacts the metonymy by assuming the shape of a Ruskinian storm-cloud: a guard reports that "suddenly a whirlwind raised a pillar/ Of dust from the ground, a storm of trouble high/ As heaven, it spread across the lowland, it tore/ Away the leaves of the trees and it filled up/ The whole huge sky" (lines 462-6; Sophocles 72). Antigone's suicide by suffocation takes this sustained chthonic metonymy to its logical conclusion, Antigone ultimately becoming a consummate figure of autochthony. ${ }^{19}$

This is also the moment when Antigone negotiates her sexual limit, because hanging was a mode of suicide that in Greek tragedy was associated with married women. "By killing herself in the manner of very feminine women," says Loraux, Antigone "found in her death a femininity that in her lifetime she had denied with all her being; she also found something like a marriage" (Tragic 32). It is a marriage on chthonic terms, however, in which

\footnotetext{
18 See also Loraux (“La main" 193).

19 See Jacobs (1996) for the analysis of the dust detail in Antigone. See Loraux (1986) for Antigone as a tragedy where Sophocles probes the meaning of auto-, especially in autokheir (suicide). By focusing on the meaning of autokheir, a deed by one's own hand, Loraux may be said to contribute to Levi-Strauss's reading of the Oedipus myth because, by killing herself with her own hand, Antigone shifts the meaning of the hand to how the hand is first chthonically imagined in the riddle of the Sphinx - as but another foot that binds man to the ground.
} 
sexual reproduction is cancelled and the narrative order reversed: Loraux calls it a wedding "in reverse" that leads "toward the home of a bridegroom called Hades" (Tragic 37). Loraux also insists that Antigone's suicide is an exception to the rules of Greek tragedy. She calls it an "exceptional death," because "what passes for a rule in the world of tragedy" is that "virgins must die by execution," with a sacrifice being made, "usually with blood shed" (Loraux, Tragic 32). This is why Antigone's suicide by suffocation fails to constitute a proper sacrifice, even though virginal weddings in reverse normally do. Instead, her suicide appears to unhinge that which passes for a rule in tragedy, and a certain narrative radicalization, or autochthony, takes place. If Antigone thus anticipates homo sacer, now in Greek tragedy (in the very instance where she negotiates her sexual limit, and where narration is radicalized), this is also how she frames the conditions of Ophelia's death. ${ }^{20}$ This in turn implies that modernity begins by challenging reproduction, perhaps canceling reproduction altogether (politico-sexual reproduction too) unless the chthonic distribution of the modern world has been taken into account as the modern world's true excess of immanence.

Ophelia rehearses and reverses Antigone in another important aspect: unlike Antigone, who begins for her tragedy with an excessive narrative credit, derived through relationships with her dead father and dead brother, Ophelia begins by being disparaged by her living father and brother, as their witless

20 By lacing Ophelia's neck with a string of violets, Millais all but traces Antigone's noose on Ophelia's throat. This is consistent with the text of Hamlet, where violets always come as chthonic marks: first, when Ophelia says that she would give "some violets" to Gertrude, Claudius and Laertes, "but they withered all when my father died" (IV.v), and second, when Laertes invites violets to spring from Ophelia's buried flesh (V.i). Millais binds them into a necklace like the ones commonly made by very young girls, with flowers used as threads for a kind of weaving. This too is consistent with Antigone's noose: Loraux remarks that "women and young girls contrived to substitute for the customary rope those adornments with which they decked themselves and which were also the emblems of their sex, as Antigone strangled herself with her knotted veil. Veils, bands, headbands - all these instruments of seduction were death traps for those who wore them" (Tragic 10). 
narrative pawn forever in need of instruction. It is only after her suicide that Laertes, at her grave, begins to value her: so that, in another curious reversal, Laertes does for Ophelia, at the end, what Antigone does for Polynices, at the beginning. Equally so with Hamlet and Haemon, the fiancés of the two heroines: unlike Antigone, Ophelia receives full sanction from Hamlet only after her suicide, not before. This explains why Hamlet's death, at the hands of Laertes (and vice versa), does not reciprocate Haemon's suicide, at the end of Antigone, but rather rehearses the narrative circumstances of the interlocking murders of Polynices and Eteocles. It is almost as if, thanks to Ophelia, Hamlet is how the story of Antigone is turned consistently inside out, into a sustained parataxis.

Ernest Jones intuited this particular Oedipal grouping in Hamlet. Even though he sidestepped Antigone in his classic Hamlet and Oedipus, Jones nonetheless insists that, "in the original Hamlet legend," Ophelia "was said to be a foster-sister of Amleth" and that "in the still earlier Norse source" she "is actually the hero's sister" (140). Jones all but stumbles upon the script of Antigone when he concludes that " $[\mathrm{m}]$ ythologicaly we have therefore to equate the Claudius (=Hamlet)-Gertrude relationship with the Laertes (=Hamlet)-Ophelia one” (140). Yet Jones proceeds by analyzing Ophelia as a figure of incest and suspends her chthonic aspect, so that the story of Antigone remains occluded as the Oedipal grouping in which Hamlet may be inflected. The same may be true of modern reception of Sophocles' Antigone broadly speaking, especially perhaps in the nineteenth century, when Antigone's attachment to the dead Polynices was habitually associated with incest. In his book about the literary afterlives of Antigone, George Steiner observes that incest may have been irrelevant to Sophocles' conception of Antigone, but the critical allure associated with incest in the nineteenth century "must be grasped if we are to make sense of the special lustre of Antigone in nineteenth-century feeling" (14). Judith Butler, too, notes Antigone's devotion "to an impossible and death-bent incestuous love of her brother" (6). 
That Hamlet, in turn, provided a template for modern appropriations of Antigone is aptly discerned by Bonnie Honig. In Honig's words, "the Hamletization of the avenger that occurs, on Schmitt's account, within the pages of Shakespeare's script has crept up on Sophocles' Antigone over time" (14748), Antigone becoming fused with Hamlet into a distinctly modern order of mourning. However, Honig notes that "[i]n Sophocles's play, the protagonist is, if anything, too decisive, not indecisive" (147) and advises against a hasty identification of Antigone with Hamlet. She thereby emancipates Antigone from Hamlet, but also implies that Hamlet may be riddled with an underanalyzed Antigonic residue; what may be at stake is a certain fundamental modern deficiency to acknowledge and understand the Antigonic aspect of Hamlet.

That Ophelia may be key to unlocking the Antigonic aspect of Hamlet is supported by the fact that Ophelia, like Antigone, is too decisive for the play's order of truth. Her suicide, like Antigone's, exceeds the idea of death, and of revenge, that the play entertains as its rationale; at the same time, this excessive death propels Hamlet towards its narrative resolution, almost against the play's will. It is therefore not only that Ophelia's suicide, like Antigone's, is excessive: her suicide is also decisive to what the play hesitates to mobilize as its future. For this reason, Ophelia's suicide may be too decisive to begin with. The same is true of Ophelia's melancholia, from which the suicide proceeds: just before he declares her melancholia to be "[a] document in madness," Laertes finds this madness more mobilizing than reasoned persuasion. ${ }^{21}$ Consequently, the very event that propels the play towards resolution is banished to take place off-stage, in what appears to be a futile attempt of the play to immunize itself against (narrative) excess and to bury this excess in a kind of (narrative) tomb or underworld. ${ }^{22}$

21 "Hadst thou thy wits, and didst persuade revenge,/ It could not move thus" (IV.v, Shakespeare 104).

22 Liz Appel alludes to a similar condition of Sophocles' play: “[T] he play itself functions 
If Ophelia's suicide is therefore a narrative match to what Schmitt describes as the intrusion of history into the play, it also calls attention to the chthonic, Antigonizing aspect of this intrusion at the heart of modernity. Schmitt himself acknowledges the chthonic aspect when he describes intrusive history as "a very hard core of reality" (38) and "the dumb rock against which the play breaks, and the surge of the truly tragic moves forward in a cloud of foam" (39). Also, Schmitt affirms the narrative as the instance where the intrusion is negotiated: he invokes the original meaning of mythos, in Greek antiquity, in order to explain how story (mythos) accommodates the intrusion and ultimately prevails over genre in tragedy - this narrative radicalization being that which, according to Schmitt, defines a tragic event. This is how Schmitt in fact claims the narrative over history for the Antigonic state of exception where modernity finds its articulation. Put differently, what happens in tragedy, as Schmitt sees it, is that narrative is forever admitted to it as an intrusion, a decisive excess, introducing into the genre the relations of metonymy and parataxis in the positions where a genre would depend on the logic of metaphor. According to Schmitt, that would be why one can have a play within a play, but not a tragedy within a tragedy, this being what distinguishes tragedy from the mourning play (38). Stretching Schmitt's point, that would be why Ophelia's suicide constitutes a Schmittian tragic event in Hamlet, and steers the play towards tragedy, whereas Hamlet's "manic proliferation of theatricality" (Santner 152) steers it towards the mourning play, to which a tragic event is admitted as a narrative homo sacer. ${ }^{23}$

as an attempt to properly bury its own heroine" and testifies "to the 'maimed rites' (pace Ophelia)" (236).

23 See also Jukić (2017) for tragic event and genre in Schmitt's Hamlet or Hecuba. In Galli's words: "The tragic, for Schmitt, is not then a substantial concept. It is a relational concept - exactly like the political, to which it is indeed, in Schmitt's thought, structurally similar" (73). See Simons (781) for Schmitt's mobilization of narrative in critical terms; Pan identifies "the importance of myth for political representation" as "a pivotal question that underlies all of Schmitt's political theory" (732). That Schmitt saw historical intrusion as chthonic (and himself as Hamlet?) can be evinced from an entry in his diary, in the 
Critics have associated Schmitt's "hard core of reality" and "dumb rock" with Lacan's concept of the real. ${ }^{24}$ In turn, Lacan acknowledges Ophelia's chthonic aspect and attaches to Ophelia a number of chthonic groupings. For instance, he calls attention to the fact that the murder of Polonius, Ophelia's father, involves "the ridiculous dragging around of his body by the feet" "Desire" 39), all but invoking the chthonic feet of Oedipus, with Ophelia as an appropriate modern Antigone. Ophelia cuts a chthonic figure for Hamlet as well, Lacan describing her as "the bait in the trap that Hamlet doesn't fall into" ("Desire" 11-12). Yet Ophelia, killing herself, eventually lures Hamlet into her tomb as the very chthonic trap that he does fall into. Indeed, Lacan also calls attention to "the furious battle at the bottom of the tomb" where "Hamlet is finally presented with the possibility of winding things up," this being the chthonic scene of Ophelia's (re)integration: it is here, says Lacan, that "we see something like a reintegration of the object a, won back ... at the price of mourning and death" ("Desire" 23-24). Finally, in his discussion of Antigone, Lacan quotes from Sophocles, about Antigone being "destined to give help, $\omega \varphi \varepsilon \lambda \varepsilon v$, to the dead," only to add - "we spoke about the same word in connection with Ophelia" (The Seminar 270). Antigone and Ophelia are thereby bound into a chthonic bait that threatens to trap Lacan's own psychoanalytic reading of Hamlet, Lacan assuming the position of Hamlet. If this means that Lacan's psychoanalysis, like Hamlet, finds its rationale in mourning (not in melancholia), it also means that it compares to Schmitt's understanding of the play (Spiel), in contradistinction to Schmitt's take on tragedy.

To be sure, Lacan ("Desire" 39) describes Hamlet as "a tragedy of the

1930s. On the day he joined the NSDAP Schmitt reports being "distressed by the insolence and arrogance' of an SA student speaker: 'often afraid of his chthonic brutality and force"' (Bendersky 133, emphasis added).

24 See Strathausen 19-20, Leonard 203. 
underworld," but associates the underworld with the "inexpiable" influence of the father's ghost on the play, to which Ophelia and Polonius are offered "in expiation," as a kind of flawed sacrifice (as sacrificial junk?). Yet Ophelia, thus flawed, persists for Lacan as that instance where the narrative overrides the play and decides its course: "it is the hour of Ophelia, the hour of her suicide, when the tragedy will run its course" ("Desire" 18). Also, it is through Ophelia that Lacan ultimately Hamletizes his Antigone, when he describes Antigone as a function of $\omega \varphi \varepsilon \lambda \varepsilon v$ : Ophelia naming the metonymic traffic between Antigone and the underworld. Ophelia, it follows, presses for a reversal in Lacan's reading of Hamlet, a reversal that corresponds in many ways to the narrative reversal of the Antigone script in Hamlet. Ophelia confronts the classic Lacanian reading of Hamlet with a demand to shift emphasis from the beginning of the play (the inexpiable paternal injunction) onto the play's resolution, which is decided on the outside of that which Hamlet imagines as the play, and in the position that the play assigns to chthonic junk. It is a shift from the play's injunctions to narrative autochthony. Again, this may be how Ophelia adumbrates the rise of the novel, which is based in narrative autochthony, against that aspect of Hamlet which remains imbued with a pre-modern understanding of politics and literature (most conspicuously perhaps in the paternal injunction with which the play opens). ${ }^{25}$

Ruskin anticipates this constellation in Modern Painters, in a brief discussion of sorrow in Shakespeare. Sorrow, according to Ruskin (Modern 233), takes "a form of blindness" in Shakespeare's tragedy, as it does in Greek tragedy. In Shakespeare, however, this "issues in little more than haste and indiscretion" (Modern 233), because Shakespeare's sorrow fails to relate to criminality, even though it may be fatal. For Ruskin, that is, crime does not

25 See Schmitt (51-53) for a medieval residue in Hamlet and especially in Benjamin's grasp of Hamlet, which Schmitt identifies as pre-political. I take injunction here as a speechact that best describes the language of the father's ghost in Hamlet; see Derrida $(7,34,50$, 116). 
seem to be tragic unless it finds a full intellectual destination in sorrow; this is why sorrow and crime, disjointed, result in nothing but "dead march and clothes of burial" at "the close of a Shakspere tragedy [sic!]" (Modern 234). Ruskin could be drawing on Schmitt here: once crime is disjointed from sorrow, its destination is not tragedy but the play, Spiel, with its theatrical show of dead marches and clothes of burial. Tellingly, Ruskin cites Ophelia, not Hamlet, as an example of this sorrow, as if to suggest that Hamlet's mourning does not qualify as sorrow in a tragic sense, whereas Ophelia's melancholia does. Without Ophelia, Ruskin seems to be saying, Hamlet would lose its tragic bearings altogether, as well as the scar of its disconnection from Greek tragedy. Like Schmitt, Ruskin implies that modern crime is fated to remain thus scarred, this being its modern condition - this also being why modernity may be profoundly tragic to begin with.

Ruskin names Antigone as Ophelia's counterpart, in that same passage of Modern Painters. For Ruskin, Antigone exemplifies Greek tragedy, because the victim in a Greek tragedy "may indeed be innocent, as Antigone, but is in some way resolutely entangled with crime, and destroyed by it, as if struck by pollution, no less than participation" (Modern 233). ${ }^{26}$ This means that Antigone forges a metonymic link between crime and the world, through pollution no less than by participation, into a sorrow which is not fully contained within subjectivity. Ruskin may be claiming a Freudian sense of melancholia for Antigone here: he all but identifies melancholia as metonymic sorrow or syntactic sorrow, in contradistinction to mourning. It should be noted that Ruskin's Victorian Ophelia and Antigone are philological as much as they are psychopolitical: to Ruskin, their metonymic sorrow is significant insofar as it binds tragedy, crime, and the world into an operative assemblage. It follows that psychoanalysis heals, into a method and a grammar, that which is syntac-

26 Sophocles associates Antigone with pollution more than once, just as pollution is associated with the chthonic, in line 838 for instance, where Hades is identified as " $[\mathrm{t}]$ he only god whom she reveres" (lines 838-9), 88. 
tic about a coming together of politics and philology in the nineteenth century; it is in this sense that Freud's psychoanalytic reading of Oedipus may have translated, into a grammar, the Antigonic syntax that was decisive both to the nineteenth-century novel and to the century's psychopolitics. Indeed, as Freud distinguishes between mourning and melancholia, Ruskin distinguishes between participation and pollution; mourning would be a psychoanalytic fit for Ruskin's participation, as melancholia would be a fit for pollution. By claiming pollution for Antigone in Modern Painters and then for the nineteenth century in the storm-cloud lectures, Ruskin suggests that participation should be revisited as a cornerstone of modernity and inflected in pollution (just as the first-person narrator of a Victorian Bildungsroman is inflected in the conditions of the focalizing consciousness). This is how the world of the Industrial Revolution, which is polluted to begin with, is admitted by Ruskin to political modernity, now as its inalienable metonymic inflection: the Industrial Revolution doing to the idea of modernity what Sophocles' Antigone does to the idea of democracy in fifth-century Athens.

Millais's Ophelia prefigures Ruskin's Antigone with a tacit demand that narrative autochthony associated with Ophelia be admitted to the Victorian ideation of industrial modernity. Millais seems to intuit that narrative autochthony, exemplified in the nineteenth century by the novel, is grasped as junk by the century's criticism and philosophy, so that the novel is to them what Ophelia is to Hamlet. The invention of the focalizing consciousness in the nineteenth century may have been how the novel itself addressed this problem, perhaps with Antigone as its template. After all, the language allocated to the focalizing consciousness in the novel, which refuses to heal into a method and a grammar, may be a match to Antigone's language, which is readily identified as flawed and faulty by critical theory. ${ }^{27}$ Like Antigone, the focalizing

27 Antigone's language has been variously described in terms of stammering, repetition, tautology, and negations (which "riddle her speech"); see Butler 68, Honig 97. The same may be true of Millais himself, who was "singularly lacking in the classical basis to his education which was still standard for other nineteenth-century middle-class boys” (Sanders 
consciousness in the nineteenth-century novel does not get to write a Bildungsroman and become a David Copperfield.

\section{Works Cited}

Agamben, Giorgio. Homo Sacer. Sovereign Power and Bare Life. Stanford UP, 1998.

Appel, Liz. “Autochthonous Antigone: Breaking Ground." Interrogating Antigone in Postmodern Philosophy and Criticism, edited by S. E. Wilmer and Audronè Žuskaukaite, Oxford UP, 2010, pp. 229-39.

Armstrong, Isobel. Victorian Glassworlds. Glass Culture and the Imagination 1830-1880.

Oxford UP, 2008.

---. "The Pre-Raphaelites and literature." The Cambridge Companion to the Pre-Raphaelites, edited by Elizabeth Prettejohn, Cambridge UP, 2012, pp. 15-31.

Armstrong, Nancy. Fiction in the Age of Photography. The Legacy of British Realism. Harvard UP, 1999.

Auerbach, Erich. Mimesis. The Representation of Reality in Western Literature. Princeton UP, 2003.

Bal, Mieke. "Myth à la lettre: Freud, Mann, Genesis and Rembrandt, and the story of the son." Discourse in Psychoanalysis and Literature, edited by Shlomith RimmonKenan, Methuen, 1987, pp. 57-89.

---. "Narration and Focalization." Narrative Theory. Critical Concepts in Literary and Cultural Studies. Volume 1. Major Issues in Narrative Theory, edited by Bal, Routledge, 2007, pp. 263-96.

Barlow, Paul. "John Everett Millais (1829-1896)." The Cambridge Companion to the PreRaphaelites, edited by Elizabeth Prettejohn, Cambridge UP, 2012, pp. 133-47. Barringer, Tim. Reading the Pre-Raphaelites. Yale UP, 1998.

Barthes, Roland. S/Z. Blackwell, 1992.

Beer, Gillian. Darwin's Plots. Evolutionary Narrative in Darwin, George Eliot and Nineteenth-Century Fiction. Cambridge UP, 2009.

$71)$. 
Bendersky, Joseph W. “Schmitt's Diaries." The Oxford Handbook of Carl Schmitt, edited by Jens Meierhenrich and Oliver Simons, Oxford UP, 2016, pp. 117-46.

Benjamin, Walter. Origin of the German Trauerspiel. Harvard UP, 2019.

Bronfen, Elisabeth. Over Her Dead Body. Death, Femininity and the Aesthetic. Manchester UP, 1996.

Brooks, Peter. Realist Vision. Yale UP, 2005.

Butler, Judith. Antigone's Claim. Kinship Between Life and Death. Columbia UP, 2000.

Caruth, Cathy. Empirical Truths and Critical Fictions. Locke, Wordsworth, Kant,

Freud. The Johns Hopkins UP, 2009.

Codell, Julie F. "Painting Keats: Pre-Raphaelite Artists Between Social Transgressions and

Painterly Conventions." Victorian Poetry, vol. 33, nos. 3-4, 1995, pp. 341-70.

---. "Empiricism, Naturalism and Science in Millais's Paintings." John Everett Millais

Beyond the Pre-Raphaelite Brotherhood, edited by Debra N. Mancoff, Yale UP, 2001, pp. 119-47.

Comay, Rebecca. "Paradoxes of Lament: Benjamin and Hamlet". Lament in Jewish

Thought, edited by Ilit Ferber and Paula Schwebel, De Gruyter, 2014, pp. 257-75.

Darwin, Charles. On the Origin of Species. Oxford UP, 2008.

Deleuze, Gilles, and Claire Parnet. Dialogues. Columbia UP, 1987.

Derrida, Jacques. Specters of Marx. The State of the Debt, the Work of Mourning and the New International. Routledge, 2006.

Dickens, Charles. “Old Lamps for New Ones." Household Words, vol. I, no. 12, 15 June 1850, pp. 265-67.

Eşanu, Octavian, editor. “Realism Today?” ARTMargins, vol. 7, no. 1, 2018, pp. 58-82.

Felman, Shoshana. "Beyond Oedipus: The Specimen Story of Psychoanalysis." Modern Language Notes, vol. 98, no. 5, 1983, pp. 1021-53.

Fludernik, Monika. "Mediacy, Mediation, and Focalization: The Squaring of Terminological Circles." Postclassical Narratology. Approaches and Analyses, edited by Jan Alber and Fludernik, The Ohio State UP, 2010, pp. 105-33.

Freud, Sigmund. The Standard Edition of the Complete Psychological Works, vol. XIV, edited by James Strachey, The Hogarth P, 1957.

Gagnier, Regenia. Subjectivities. A History of Self-Representation in Britain, 1832-1920. Oxford UP, 1991. 
Gallagher, Catherine. The Industrial Reformation of English Fiction. Social Discourse and Narrative Form 1832-1867. The U of Chicago P, 1985.

Galli, Carlo. "Hamlet: Representation and the Concrete." Political Theology and Early Modernity, edited by Graham Hammill and Julia Reinhard Lupton. The U of Chicago P, 2012, pp. 60-83.

Gaskell, Elizabeth. North and South. Oxford UP, 1982.

Gates, Barbara. Victorian Suicide. Mad Crimes and Sad Histories. Princeton UP, 1988.

Grieve, Alastair. “Ruskin and Millais at Glenfinlas.” The Burlington Magazine, vol. 138, no. 1117, 1996, pp. 228-34.

Hares-Stryker, Carolyn, editor. An Anthology of Pre-Raphaelite Writings. Sheffield Academic P, 1997.

Heidegger, Martin. What is Called Thinking? Harper \& Row, 1968.

Honig, Bonnie. Antigone, Interrupted. Cambridge UP, 2013.

Hobsbawm, Eric. The Age of Revolution, 1789-1848. Vintage, 1996.

Jacobs, Carol. “Dusting Antigone.” Modern Language Notes, vol. 111, no. 5, 1996, pp. 889917.

Jones, Ernest. Hamlet and Oedipus. Norton, 1976.

Jukić, Tatjana. Zazor, nadzor, svidanje. Dodiri književnog i vizualnog u britanskom 19. stoljeću. Zavod za znanost o književnosti Filozofskoga fakulteta Sveučilišta u Zagrebu, 2002.

---. 2017. "Cavell's Shakespeare, or the Insufficiency of Tragedy for Modernity." Bollettino Filosofico, vol. 32, pp. 67-87.

Lacan, Jacques. "Desire and the Interpretation of Desire in Hamlet." Yale French Studies, vols. 55/56, 1977, pp. 11-52.

---. The Seminar of Jacques Lacan. Book VII. The Ethics of Psychoanalysis, edited by Jacques-Alain Miller, Norton, 1997.

Leonard, Miriam. "Carl Schmitt: Tragedy and the Intrusion of History." Tragedy and the Idea of Modernity, edited by Joshua Billings and Leonard, Oxford UP, 2015, pp. 194-211.

Lévi-Strauss, Claude. Structural Anthropology. Basic Books, 1963.

Levine, George. Realism, Ethics and Secularism: Essays on Victorian Literature and Science. Cambridge UP, 2008. 
Loraux, Nicole. "La main d'Antigone." Mètis. Anthropologie des mondes grecs anciens, vols. 1/2, 1986, pp. 165-96.

---. Tragic Ways of Killing a Woman. Harvard UP, 1987.

Meierhenrich, Jens, and Oliver Simons. "A Fanatic of Order in an Epoch of Confusing Turmoil': The Political, Legal, and Cultural Thought of Carl Schmitt.” The Oxford Handbook of Carl Schmitt, edited by Meierhenrich and Simons, Oxford UP, 2016, pp. 3-70.

Menke, Christoph. "The Possibility of Revolution." Crisis \& Critique, vol. 4, no. 2, 2017, pp. 314-24.

Millais, J.G. The Life and Letters of Sir John Everett Millais. Methuen, 1899.

Miller, J. Hillis. “Henry James and 'Focalization,' or Why James Loves Gyp." A

Companion to Narrative Theory, edited by James Phelan and Peter J. Rabinowitz, Blackwell, 2005, pp. 124-35.

Mumford, Lewis. Technics and Civilization. Routledge \& Kegan Paul, 1934.

---. The Culture of Cities. Harcourt Brace Jovanovich, 1970.

Oak Taylor, Jesse. "Storm-Clouds on the Horizon: John Ruskin and the Emergence of the Anthropogenic Climate Change." Interdisciplinary Studies in the Long Nineteenth Century, vol. 26, 2018, pp. 1-19, doi.org/10.16995/ntn.802. Accessed 15 Apr. 2020.

Pan, David. "Tragedy as Exception in Carl Schmitt’s Hamlet or Hecuba." The Oxford Handbook of Carl Schmitt, edited by Jens Meierhenrich and Oliver Simons, Oxford UP, 2016, pp. 731-50.

Peterson, Kaara L., and Deanne Williams. "Introduction: The Afterlives of Ophelia." The Afterlife of Ophelia, edited by Peterson and Williams, Palgrave Macmillan, 2012, pp. 1-9

Rhodes, Kimberly. “Degenerate Detail: John Everett Millais and Ophelia’s 'Muddy Death." John Everett Millais Beyond the Pre-Raphaelite Brotherhood, edited by Debra N. Mancoff, Yale UP, 2001, pp. 43-68.

Rose, Andrea. The Pre-Raphaelites. Phaidon P, 1992.

Ruskin, John. Modern Painters, vol. 5, George Allen, 1897.

---. "The Storm-Cloud of the Nineteenth Century." The Complete Works, vol. XXIV, The Kelmscott Society, 1900, pp. iii-68. 
---. Modern Painters, vol. 3, Routledge, 1907.

Said, Edward. "Introduction." Mimesis. The Representation of Reality in Western Literature by Erich Auerbach, Princeton UP, 2003, pp. i-xxiv.

Sanders, Andrew. "Millais and Literature." John Everett Millais Beyond the Pre-Raphaelite Brotherhood, edited by Debra N. Mancoff, Yale UP, 2001, pp. 69-93.

Santner, Eric L. The Royal Remains. The People's Two Bodies and the Endgames of Sovereignty. The U of Chicago P, 2011.

Schmitt, Carl. Hamlet or Hecuba. Plutarch P, 2006.

Shakespeare, William. Hamlet. The Cambridge Dover Wilson Shakespeare, vol. 7, Cambridge UP, 2009.

Showalter, Elaine. "Representing Ophelia: women, madness, and the responsibilities of feminist criticism." Shakespeare and the Question of Theory, edited by Patricia Parker and Geoffrey Hartman, Methuen, 1985, pp. 77-94.

Simons, Oliver. "Carl Schmitt's Spatial Rhetoric." The Oxford Handbook of Carl

Schmitt, edited by Jens Meierhenrich and Oliver Simons, Oxford UP, 2016, pp. 776- 802.

Sloterdijk, Peter. Rage and Time. A Psychopolitical Investigation. Columbia UP, 2010.

Smith, Lindsay. Victorian Photography, Painting and Poetry. The Enigma of Visibility in Ruskin, Morris and the Pre-Raphaelites. Cambridge UP, 1995.

Sophocles. Antigone. Oxford UP, 2003.

Steiner, George. Antigones. How the Antigone Legend Has Endured in Western Literature, Art, and Thought. Yale UP, 1996.

Strathausen, Carsten. "Myth or Knowledge: On Carl Schmitt’s Hamlet or Hecuba." Telos, vol. 153, Winter 2010, pp. 1-23.

Teschke, Benno. “Carl Schmitt's Concepts of War: A Categorical Failure.” The Oxford Handbook of Carl Schmitt, edited by Jens Meierhenrich and Oliver Simons, Oxord UP, 2016, pp. 367-400. 